\title{
PENGARUH PERTUMBUHAN EKONOMI DAN INVESTASI TERHADAP KETIMPANGAN PENDAPATAN DI KABUPATEN/KOTA PROVINSI NUSA TENGGARA BARAT
}

Mohammad Royan, Wahyu Hidayat Riyanto, Ida Nuraini

Program Studi Ekonomi Pembangunan, Fakultas Ekonomi dan Bisnis, Universitas Muhammadiyah Malang, Jl.Raya Tlogomas No.246 Malang, Indonesia

* Corresponding author: Royanmohammad10@gmail.com

\begin{tabular}{|c|c|}
\hline Artikel Info & Abstract \\
\hline Article history: & The distinction of interzonal potential will cause several \\
\hline Received 23 May 2019 & problems such as uneven economic growth, the area-centered \\
\hline Revised 29 May 2019 & spreading investment, and income inequality. This research \\
\hline Accepted 21 June 2019 & aims to analyze the effect of economic growth and investment \\
\hline $\begin{array}{l}\text { Available online } 26 \text { June } \\
2019\end{array}$ & $\begin{array}{l}\text { on the inter-regional income inequality in West Nusa } \\
\text { Tenggara from } 2012 \text { to 2017. This research uses secondary } \\
\text { data obtained from BPS-Statistics Indonesia (Badan Pusat }\end{array}$ \\
\hline $\begin{array}{l}\text { Keyword: Income inequality; } \\
\text { economy growth; investment }\end{array}$ & $\begin{array}{l}\text { Statistik), and the Indonesian Investment Coordinating Board } \\
\text { (Badan Koordinasi Penanaman Modal - BPKM). } \\
\text { Williamson Index is used to representing income inequality, } \\
\text { and the method analysis is the panel data analyzing with a }\end{array}$ \\
\hline JEL Classification & $\begin{array}{l}\text { Fixed Effect Model (FEM). The effect between a dependent } \\
\text { variable and independent variable will be shown that economic } \\
\text { growth has a positive and significant influence towards the } \\
\text { income inequality, and investment has a positive and not } \\
\text { significant influence towards the income inequality. }\end{array}$ \\
\hline
\end{tabular}

\section{PENDAHULUAN}

Ketimpangan wilayah terjadi akibat ada nya kondisi perbedaan kandungan sumber daya alam dan perbedaan kondisi geografis pada setiap daerah. Perbedaan kondisi ini dapat mempengaruhi kemampuan produksi baik barang maupun jasa pada daerah, karena sumberdaya alam sendiri merupakan salah satu faktor penting dalam melakukan produksi. Kondisi dimana suatu daerah memiliki sumberdaya alam yang lebih tinggi untuk memproduksi barang atau jasa akan mendorong pertumbuhan ekonomi daerah yang lebih cepat, begitu pula sebaliknya jika daerah memiliki sumber daya alam yang lebih rendah untuk melakukan produksi barang atau jasa.

Kemampuan untuk memproduksi barang dan jasa sendiri merupakan hal yang penting dalam proses pembangunan baik pada level nasiol maupun regional. Proses pembanguna nasional sendiri bertujuan untuk mencapai pembangunan smberdaya secara efisien, efektif, berkeadilan, dan berkenlajutan. Salah satu bagian yang penting dari pembangunan ialah pembangunan ekonomi, hal ini dikarenakan pertumbuhan ekonomi merupakan suatu proses pembangunan multidimensional (Todaro \& Smith, 2011:15). Setiap pemerintah daerah

memiliki peran untuk mengoptimalkan setiap sumberdaya yang dimiliki demi mencapai pembangunan ekonomi yang berkualitas, seperti yang telah diatur dalam pemberlakuan otonomi daerah tahun 2001. Pemanfaatan sumberdaya alam, masyarakat, dan pemerintah merupakan kolaborasi yang berkualitas untuk mewujudkan pembangunan daerah yang berkualitas dan berkelanjutan (Boedirachminarni \& Suliswanto, 2017). 
Pembangunan ekonomi bertujuan untuk menghasilkan pertumbuhan ekonomi yang baik serta megurangi kemiskinan dan ketimpangan pendapatan. permasalahan yang harus dihadapi negara berkembang yang pada umumnya terlalu berfokus mengejar pertumbuhan ekonomi adalah tingkat pertumbuhan output antar daerah yang tidak merata. Tetapi di sisi lain ketika menunda untuk melakukan pemerataan pada tahap berikutnya, pertumbuhan ekonomi yang telah tumbuh akan mempermudah mencapai pemerataan atau pemerataan dapat terjadi dengan sendirinya (trickel down effect) (Nuraini, 2012).

Pembangunan ekonomi biasanya berkaitan dengan perkembangan ekonomi, pembangunan ekonomi dalam arti lain sering dipahami sebagai pertumbuhan ekonomi yang diikuti oleh perubahan dalam struktur dan corak kegiatan ekonomi, hal ini dilihat bahwa pembangunan ekonomi tidak hanya dipengaruhi oleh masalah perkembangan pendapatan nasional riil akan tetapi dapat dipengaruhi oleh modernisasi kegiatan ekonomi. Selain itu terdapat perbedaan antara pembangunan ekonomi dan pertumbuhan ekonomi yakni dalam pembangunan ekonomi meyakini bahwa pembangunan ekonomi akan diikuti pendapatan perkapita akan selalu mengalami peningkatan, sedangkan pertumbuhan ekonomi meyakini bawa pertumbuhan ekonomi tidak selalu berbanding lurus dengan kenaikan pendapatan perkapita.

Pertumbuhan ekonomi sendiri merupakan tolak ukur dari keberhasilan pembangunan ekonomi baik di level nasional nasional maupun regional. pertumbuhan ekonomi yang tinggi memang diperlukan untuk mendongkrak pembangunan ekonomi. Permasalah pembangunan seperti kemiskinan, pengangguran, dan ketimpangan diyakini dapat diatasi hanya dengan pertumbuhan ekonmi yang tinggi (Susilowati, Sri, \& Suliswanto, 2015).

Sebagai indikator untuk mengukur pertumbuhan ekonomi, nilai PDRB menunjukkan terjadinya perubahan pada pada setiap periodenya, dimana semakin tinggi persentase perubahan PDRB pada suatu daerah maka semakin besar pula pendapatan yang diperoleh masyarakat. Ketika perubahan PDRB semakin tinggi maka semakin sejahtera pula penduduk suatu wilayah, dan ketika pendapatan tinggi terjadi merata antar daerah maka ketimpangan pendapatan akan berkurang. Tetapi permasalahan yang terjadi di Indonesia peubahan $\mathrm{PDRB} /$ pertumbuhan ekonomi antar wilayah berbeda, sehingga yang terjadi pendapatan yang diperoleh oleh penduduk suatu daerah dengan daerah lain berbeda satu sama lain.

Perubahan pada laju pertumbuhan ekonomi Provinsi Nusa Tenggara Barat merupakan usaha pemerintah daerah dalam meningkatkan pendapatan yang diperoleh masyarakat. Terdapat beberapa hal yang dapat meningkatkanpertumbuhan ekonomi menurut Sukirno, $(2006 ; 268)$ dalam meningkatkan tingkat atau laju pertumbuhan ekonomi ditentukan oleh empat faktor : (i) Luas lahan (sumberdaya alam); (ii) jumlah dan perkembangan penduduk; (iii) jumlah stok modal dan perkembangannya; dan (iv) perkembangan teknologi. Selain itu menurut Arifin, (2012) perumusan kebijakan dan program pembangunan daerah yang berfokus pada penyediaan lapangan pekerjaan atau industri padat karya dapat mendongkrak pertumbuhan ekonomi. Menurut Kusuma, (2016) salah satu usaha dalam mendongkrak pertumbuhan ekonomi daerah, dapat dilakukan desentralisasi 
fiskal. Dengan kebijakan ini diharapkan dapat mendorong setiap institusi untuk dapat bersaing secara global.

Ketimpangan pendapatan sendiri tidak hanya disebabkan oleh pertumbuhan ekonomi saja melainkan ada pula faktor lain yang menyebabkan terjadinya ketimpangan pendapatan seperti perbedaan tingkat investasi antar wilayah. Investasi sendiri merupakan salah satu instrumen yang dapat meningkatkan kemampuan produksi suatu wilayah, hal ini dikarenakan bertambahnya modal yang masuk akan meningkatkan kemampuan produksi barang dan jasa. Investasi sendiri dapat diartikan sebagai penanaman modal yang dilakukan pada suatu perusahaan atau daerah tertentu. Penanaman modal sendiri dapat bersumber dari dalam maupun luar negeri, ketika terdapat penambahan investasi maka akan meningkatkan jumlah produktifitas yang akan berujung pula dengan meningkatnya kemampuan penyerapan tenaga kerja. Dengan meningkatnya tenaga kerja yang dapat terserap dan akan berimbas pula pada daya beli masyarakat yang meningkat, dimana akan berpengaruh pada pendapatan perkapita.

Investasi yang dilakukan baik dari dalam maupun luar negeri dapat menjadi salah satu faktor yang menyebabkan terjadinya ketimpangan pendapatan. Banyaknya Investasi yang terpusat dibeberapa daerah merupakan alasan terjadinya ketimpangan, dan tidak menuntut kemungkinan bahwa tingkat investasi yang ada pada satu daerah sangat tinggi dan pada daerah yang lain memiliki tingkat investasi sangat rendah. Salah satu alasan investor menanamkan modal ialah melihat dari potensi sumber daya alam, keamanan, infrastruktur, kepastian informasi dan kemudahan birokrasi yang dimiliki oleh daerah, sehingga akan terbentuk nilai investasi yang berbeda pada setiap wilayah.

Meningkatnya investasi dan pertumbuhan ekonomi yang positif pada suatu wilayah merupakan hal yang baik, bakan hal itulah yang menjadi tujuan dari pemerintah di setiap daerah. Tetapi ketika tingginya tingkat investasi dan pertumbuhan ekonomi hanya terpusat pada beberapa wilayah saja maka akan menimbulkan permasalahan jangka panjang seperti ketimpangan pendapatan. Ketika investasi yang terpusat pada suatu wilayah meneyebabkan kemampuan produksi pada wilayah lain tetap bahkan cenderung menurun sedangkan pada dasarnya pertumbuhan ekonomi tidak selalu berkorelasi positif dengan pemerataan. Adanya korelasi yang tidak selalu positif dapat diartikan terdapat trade off, dimana saat pembanguanan ekonomi lebih berfokus untuk melakukan permerataan maka akan memakan waktu yang lebih lama dalam mencapai tingkat yang lebih tinggi, dan begitu pula sebaliknya ketika pembangunan berfokus pada pencapaian tingkat pertumbuhan ekonomi yang lebih tinggi maka potensi terjadinya ketimpangan dalam distribusi pendapatan akan lebih tinggi pula (Kuncoro, 2004).

Pada penelitian ini lokasi yang akan digunakan sebagai bahan penelitian adalah Provinsi Nusa Tenggara Barat yang terdiri atas 8 kabupaten, dan 2 kota. Pemilihan obyek didasarkan pada tingginya tingkat pertumbuhan ekonomi dimana rata-rata pertumbuhan ekonomi pada kurun waktu 5 (lima) tahun yaitu pada tahun 2012 - 1017, terutama pada tahun 2015 yang menjadikan Nusa Tenggara Barat menjadi Provinsi dengan pertumbuhan ekonomi paling tinggi 
di indonesia. Ketika kondisi pertumbuhan ekonomi pada tingkat regional baik, justru menimbulkan permasalahan yang muncul pada tingkat wilayah seperti ketimpangan pendapatan yang terjadi di kabupaten/kota. Ketimpangan pendapatan yang terjadi tidak hanya dipicu oleh perumbuhan ekonomi antar wilayah yang tidak seimbang saja, meliankan dapat pula dipicu oleh tidak seimbang-nya alokasi investasi antar wilayah.

Berdasarkan hal tersebut beberapa faktor yang dapat mempengaruhi ketimpangan pendapatan adalah pertumbuhan ekonomi yang terjadi tidak merata, dan alokasi investasi yang tersebar tidak merata. Berdasarkan penjelasan tersebut maka inti dari permasalah yang terdapat pada penelitian ini akan dirumuskan dalam pertanyaan, Seberapa besar pengaruh tingkat pertumbuhan ekonomi dan investasi terhadap ketimpangan pendapatan di kabupaten/kota Provinsi Nusa Tenggara Barat?.

Menurut syafrizal dalam Aggina and Artaningtyas, (2017) ketimpangan pada negara yang sedang berkembang relatif memiliki tingkat lebih tinggi dibanding dengan negara maju hal ini disebabkan pada saat pembangunan baru di mulai, kesempatan dan peluang yang ada dimanfaatkan oleh daerah yang memiliki kondisi pembangunan baik sedangkan untuk daerah yang kondisi pembangunannya masih kurang baik/ terbelakang belum mampu untuk memanfaatkan peluang tersebut karena terkendala oleh rendahnya sarana dan prasarana serta kualitas dari sumberdaya manusia yang rendah pula. Dari permasalahan tersebut dapat kita pahami bahwa pertumbuhan ekonomi pada daerah dengan kondisi yang baik cenderung lebih cepat dibandingkan dengan daerah dengan kondisi yang kurang baik.

Kuznet (dalam Lincolin, 2010: 292) menjelaskan bahwa pembangunan di stuatu negara pada batas-batas tertentu dapat memicu timbulnya kesenjangan ekonomi diantara warganya. Dalam analisinya, Kuznets menemukan relasi antara tingkat kesenjangan pendapatan dan tingkat pendapatan per kapita berbentuk U terbalik, yaitu menyatakan bahwa pada awal tahap pertumbuhan, distribusi pendapatan atau kesejahteraan cenderung memburuk. Namun, pada tahap-tahap berikutnya, distribusi pendapatan akan membaik seiring meningkatnya pendapatan per kapita. Menurut Wie (dalam Litantia, 2010: 8) mengatakan bahwa pertumbuhan perekonomian di suatu negara yang pesat dapat terjadi ketimpangan pendapatan yang tinggi apabila permasalahan kemiskinan dan pengangguran belum teratasi.

Berdasar dari teori Harrod-Domar dalam Hartini, (2017) yang menjelaskan tentang adanya korelasi yang bernilai positif antara tingkat investasi dengan laju pertumbuhan ekonomi, maka dapat diambil kesimpulan bahwa dengan minimnya nilai invesatasi pada satu wilayah akan menyebabkan pertumbuhan ekonomi dan tingkat pendapatan masyarakat perkapita wilayah tersebut rendah yang disebabkan oleh kurangnya kegiatan-kegiatan ekonomi yang produktif. Faktor medasar yang dapat menyebabkan adanya ketimpangan pada pembangunan ekonomi adalah ketimpangan distribusi investasi karena adanya keterpusatan investasi hanya pada beberapa wilayah.

Berdasarkan penelitian terdahulu pertumbuhan ekonomi diketahui memiliki pengaruh yang signifikan terhadap ketimpangan pendapata. Hal ini diketahui dari penelitian yang dilakukan oleh Adipuryanti dan Sudibia, (2013), 
Saputra, (2016), dan Sultan \& Sodik, (2010). Berdasarkan penelitian terdahulu diketahui bahwa investasi berpengaruh tidak signifikan terhadap ketimpangan pendapatan dapat dilihat dari penelitian yang dilakukan oleh Hartini, (2017), Nangarumba, (2015), dan Adipuryanti dan Sudibia, (2013). Berbeda dari yang lainnya penelitian yang dilakukan oleh Pradnyadewi \& Purbadharmaja, (2017) menunjukkan bahwa investasi memiliki pengaruh yang tidak signifikan terhadap ketimpangan pendapatan.

\section{METODE PENELITIAN}

Penelitian ini merupakan penelitian kuantitatif, subjek penelitian merupakan 9 Kabupaten/kota di Provinsi Nusa Tenggara Barat dengan observasi sebanyak 54. Pada penelitian ini yang menjadi objek penelitian adalah pertumbuhan ekonomi, investasi, dan ketimpangan pendapatan tahun 2012-2017. Data yang digunakan merupakan data skunder, dengan teknik pengumpulan data menggunakan dokumentasi yang diperoleh dari Badan Pusat Statistik (BPS), dan Badan Koordinasi Penanaman Modal (BKPM).

Dalam penelitian ini digunakan gunakan 3 (tiga) variabel yang terbagi menjadi variabel dependen (terikat) dan variabel independent (Bebas). Variabel terikat merupakan veriabel yang dapat berubah jika terdapat perubahan pada variabel bebas atau dapat dikatakan bahwa variabel ini dipengaruhi oleh veriabel bebas. Pada penelitian ini variabel terikat yang digunakan adalah ketimpangan pendapatan antar Kabupaten/kota di Provinsi Nusa Tenggara Barat.

Ketimpangan pendapatan merupakan suatu kondisi dimana terjadi timpangnya pendapatan pada 10 wilayah yang berbeda, kondisi ini diketahui dengan menggunakan Indeks Williamson dengan rumus sebagai berikut :

$$
I W=\frac{\sqrt{\sum\left(Y_{i}-Y\right)^{2} f i / n}}{Y}
$$

Keterangan :

$I W \quad=$ Indeks Williamson

$Y i=$ PDRB per kapita kabupaten/kota di Provinsi Nusa Tenggara barat

$Y \quad=$ PDRB per kapita Provinsi Nusa Tenggara barat

$f i \quad=$ Jumlah penduduk

Untuk mengukur ketimpangan pendapatan indeks williamson, IW berkisar antara 0-1 dengan keterangan sebagai berikut:

a. <0,3 : Ketimpangan Pendapatan rendah,

b. 0,3-0,5: Ketimpangan Pendapatan sedang, dan

c. $>0,5$ : Ketimpangan Pendapatan tinggi.

Variabel bebas merupakan faktor yang mempengaruhi variabel terikat. Pada penelitian ini digunakan variabel bebas adalah pertumbuhan ekonomi, dan investasi pada kabupaten/kota di provinsi Nusa Tenggara Barat. Pertumbuhan ekonomi merupakan perubahan relatif pada nilai riil PDRB, 
pertumbuhan ekonomi dapat diketahui dari PDRB harga konstan 2010 dan dinyatakan dalam satuan persen. Investasi merupakan pengeluaran yang dilakukan penanam modal yang bertujuan untuk meningkatkan produksi pada jangka waktu yang lama yang akan dinyatakan dengan satuan us dolar.

Teknik analisis data yang digunakan dalam penelitian ini menggunakan teknik analisis regresi data panel dengan persamaan model Ordinary Least Square (OLS) sebagai berikut :

$$
Y_{i t}=\beta_{1}+\beta_{2} X 1_{i t}+\beta_{3} X 2_{i t}+v_{i t}
$$

Keterangan:

$\begin{array}{ll}\mathrm{Y} & : \text { Ketimpangan pendapatan } \\ \beta_{1}, \beta_{2}, \beta_{3} & : \text { Koefisien Regresi } \\ \mathrm{X} 1 & : \text { Pertumbuhan Ekonomi } \\ \mathrm{X} 2 & : \text { Investasi } \\ \mathrm{i} & : \text { Kabupaten/kota } \\ \mathrm{t} & : \text { Tahun }\end{array}$

\section{HASIL DAN PEMBAHASAN}

Analiss ketimpangan pendapatan di kabupaten/kota Provinsi Nusa Tenggara Barat menggunakan Indeks williamson. Rata-rata tingkat ketimpangan di kabupaten/kota Provinsi Nusa Tenggara Barat selama kurun waktu 5 tahun menunjukkan akan ditunjukkan pada tabel 1 berikut ini :

Tabel 1. Rata-Rata Indeks Williamson Kabupaten/Kota di Provinsi Nusa Tenggara Barat Tahun 2012-2017

\begin{tabular}{lr}
\hline \multicolumn{1}{c}{ Kabupaten/kota } & Rata-rata \\
\hline Kabupaten Lombok Barat & 0.18 \\
Kabupaten Lombok Tengah & 0.26 \\
Kabupaten Lombok Timur & 0.31 \\
Kabupaten Sumbawa & 0.09 \\
Kabupaten Dompu & 0.08 \\
Kabupaten Bima & 0.15 \\
Kabupaten Sumbawa Barat & 0.57 \\
Kabupaten Lombok Utara & 0.10 \\
Kota Mataram & 0.04 \\
\hline
\end{tabular}

Sumber : BPS Nusa Tenggara Barat,(data diolah)

Berdasarkan Tabel 1 dapat diketahui bahwa hasil perhitungan menggunakan indeks williamson pada setiap daerah berbeda. Rata-rata Indeks williamson menunjukkan terdapat 1 daerah yang diklasifikasikan memiliki ketimpangan pendapatan tinggi yaitu daerah yang memiliki rata-rata indeks williamson $>0.5$ yaitu Kabupaten Sumbawa Barat. Daerah dengan kalsifikasi ketimpangan pendapatan rendah yaitu daerah dengan indek williamson $<0,3$ berjumlah 8 daerah antara lain Kabupaten Sumbawa, Kabupaten Dompu, 
Kabupaten Bima, Kabupaten Lombok Utara, Kota Mataram, Kabupaten Lombok Barat, Kabupaten Lombok Tengah, dan Kabupaten Lombok Timur.

Sebagai indikator dalam memenentukan kondisi perekonomian pada Kabupaten/kota Provinsi Nusa Tenggara Barat, digunakan PDRB menurut harga konstan Untuk mengetahui persentase pertumbuhan ekonomi. PDRB menurut harga konstan digunakan agar nilai yang diperoleh terbebas dari inflasi sehingga sifatnya riil.

Tabel 2. Rata-Rata Pertumbuhan Ekonomi Kabupaten/Kota Provinsi Nusa Tenggara Barat Tahun 2012-2017

\begin{tabular}{lr}
\hline \multicolumn{1}{c}{ Tahun } & $\begin{array}{c}\text { Rata- } \\
\text { rata }\end{array}$ \\
\hline Kabupaten Lombok Barat & 5,78 \\
Kabupaten Lombok Tengah & 7,32 \\
Kabupaten Lombok Timur & 5,52 \\
Kabupaten Sumbawa & 6,37 \\
Kabupaten Bima & 6,19 \\
Kabupaten Sumbawa Barat & 6,06 \\
Kabupaten Lombok Utara & 11,87 \\
Kota Mataram & 4,78 \\
\hline Sumber: BPS Nusa Tenggara Barat,(data diolah) &
\end{tabular}

Berdasarkan Tabel 2 rata-rata pertumbuhan ekonomi pada kabupaten/kota, Kabupaten Sumbawa Barat memiliki rata-rata pertumbuhan ekonomi terbesar yaitu 18,03 \%. Kebupaten Lombok Tengah merupakan kabupaten dengan pertumbuhan ekonomi terbesar kedua yaitu sebesar 7,50\%, sedangkan Kabupaten lombok Utara menjadi daerah dengan pertumbuhan ekonomi terendah yaitu sebesar $4,5 \%$

Investasi atau modal merupakan salah satu faktor yang dapat meningkatkan kegiatan ekonomi dan kesempatan kerja melalui peningkatan faktor-faktor produksi yang ada. Kemampuan pemerintah daerah dalam mengelolah potensi daerah dapat meningkatkan kepercayaan serta minat investor dalam menanamkan investasinya. Investasi yang merupakan input dari produksi bersumber dari dalam maupun luar negeri.

Tabel 3. Total Penanaman Modal Asing (PMA) Kabupaten/kota Provinsi Nusa Tenggara Barat Tahun 2012-2017 (\$ 000)

\begin{tabular}{lr}
\hline \multicolumn{1}{c}{ Kabupaten/kota } & \multicolumn{1}{c}{ Total } \\
\hline Kabupaten Lombok Barat & $82.396,09$ \\
Kabupaten Lombok Tengah & $49.570,12$ \\
Kabupaten Lombok Timur & $42.221,65$ \\
Kabupaten Sumbawa & $2.508 .268,68$ \\
Kabupaten Dompu & $4.919,81$ \\
Kabupaten Bima & $9.511,89$ \\
Kabupaten Sumbawa Barat & $32.289,04$
\end{tabular}

(dilanjutkan pada hal 8) 
Sumber : BPS Nusa Tenggara Barat,(data diolah)

Berdasarkan Tabel 3 dapat diketahui bahwa terdapat berbedaan total nilai investasi yang cukup tinggi antar daerah di Provinsi Nusa Tenggara Barat dalam kurun waktu lima tahun. Kabupaten Sumbawa merupakan kabupaten dengan total investasi tertinggi sebesar $\$ 2.508 .268 .680$. kemudian di peringkat kedua adalah Kota Mataram sebesar \$ 141.772.070, dan Kabupaten Lombok Barat merupakan peringkat ke tiga sebesar \$82.396.090, sedangkan untuk daerah dengan penanaman modal asing terendah adalah Kabupaten Dompu yaitu sebesar \$ 4.919.810.

Pengaruh pertumbuhan ekonomi dan Investasi terhadap ketimpangan pendapatan di Kabupaten/Kota Provinsi Nusa Tenggara Barat dianalisa menggunakan eviews. Dalam menentukan model yang tepat pada penelitian ini, dilakukan pengujian model. Pengujian model yang pertama menggunakan Uji Chow, pengujian ini digunakan untuk memilih antara model OLS (Common Effect Model) tanpa Dummy Variabel atau Fixed Effect Model. Berdasarkan hasil perhitungan diketahui Probabilitas Cross-section Chi-square sebesar 0,0000 < 0,05, maka H0 ditolak dan H1 diterima atau Fixed Effect Model merupakan model yang tepat untuk digunakan dalam penelitian ini.

Selanjutnya dilakukan uji Haussman, pengujian ini digunakan untuk memilih antara Fixed Effect Model atau Random effect Model. Berdasarkan hasil perhitungan diketahui Probabilitas Cross-section random sebesar 0,0031 $<0,05$, maka H0 ditolak dan H1 diterima atau Fixed Effect Model merupakan model yang tepat untuk digunakan dalam penelitian ini. Berdasarkan hasil pengujian model maka analisis regresi data panel yang telah dilakukan untuk mengetahui seberapa jauh pertumbuhan ekonomi dan investasi terhadap ketimpangan pendapatan di kabupaten/kota Provinsi Nusa Tenggara Barat menggunakan Fixed Effect Model (FEM) diperoleh persamaan sebagai berikut:

Tabel 4. Hasil Data Regresi Fixed Effect Model

\begin{tabular}{crllr}
\hline Variable & Coefficient & Std. Error & t-Statistic & Prob. \\
\hline C & 0.217189 & 0.028718 & 7.562841 & 0.0000 \\
X1? & 0.151130 & 0.036255 & 4.168546 & 0.0001 \\
LOG(X2?) & 0.002994 & 0.002789 & 1.073616 & 0.2890 \\
\hline R-squared & 0.952254 & F-statistic & 85.75927 \\
Adjusted R-squared & 0.941150 & Prob(F-statistic) & 0.000000 \\
\hline
\end{tabular}

Berdasarkan Tabel 4. diperoleh model pada penelitian ini akan dijelaskan dengan rumus sebagai berikut :

$$
\mathrm{IW}_{\text {it }}=0,217189+0,151130 \mathrm{X}_{\text {lit }}+0,002994 \mathrm{X}_{2 \mathrm{it}}
$$


Variabel (C) bernilai 0,217189, hal ini berarti ketika variabel pertumbuhan ekonomi dan investasi di kabupaten/kota Provinsi Nusa Tenggara Barat bernilai konstan ( tidak berubah), maka nilai indeks williamson sebesar 0,217189. Variabel pertumbuhan ekonomi berpengaruh positif terhadap ketimpangan pendapatan di kabupaten/kota Provinsi Nusa Tengara Barat dengan koefisien regresi sebesar 0.151130 dengan probabilitas sebesar 0.0001 atau $\mathrm{X} 1 \leq \square(0,05)$ dan thitung $(4,168546)>$ ttabel $(1,67528)$, sehingga dapat disimpulkan bahwa pertumbuhan ekonomi berpengaruh signifikan terhadap ketimpangan pendapatan. Hal ini berarti apabila variabel pertumbuhan ekonomi meningkat sebanyak $1 \%$ pertahun, maka ketimpangan pendapatan di kabupaten/kota Provinsi Nusa Tenggara Barat akan meningkat sebanyak 0.151130 pertahun.

Variabel investasi berpengaruh positif terhadap ketimpangan pendapatan di kabupaten/kota Provinsi Nusa Tenggara Barat dengan koefisien regresi sebesar 0.002994 dengan probabilitas sebesar 0.2890 atau X2 $\geq \square(0,05)$ dan dan thitung $(1,073616)<$ ttabel $(1,67528)$ sehingga dapat disimpulkan bahwa investasi berpengaruh tidak signifikan terhadap ketimpangan pendapatan.. Hal ini berarti apabila Variabel investasi meningkat sebanyak \$ 1.000 pertahun, maka ketimpangan pendapatan di kabupaten/kota Provinsi Nusa Tenggara Barat akan meningkat sebanyak 0.002994 pertahun, , meskipun peningkatan yang terjadi tidak besar atau tidak nyata (tidak signifikan). Secara simultan yang ditunjukkan dengan nilai probabilitan f-statistic sebesar 0,0000 atau kurang dari $\square(0,05)$ dan nilai fhitung $=85,75927$ dengan $\mathrm{ftabel}=2,83$, atau fhitung $>$ ftabel, sehingga dapat disimpulkan bahwa pertumbuhan ekonomi dan investasi secara simultan berpengaruh signifikan terhadap ketimpangan pendapatan. Nilai koefisien determinasi (Adjusted R2) atau goodness of fit sebesar 0,952254. Hal ini menunjukkan bahwa variabel bebas pada penelitian ini mampu menjelaskan variabel terikat sebesar $95 \%$, sedangkan sisanya $5 \%$ dijelaskan variabel lain diluar model yang tidak dibahas pada penelitian ini.

\section{KESIMPULAN DAN SARAN}

Berdasarkan hasil analisis yang telah dilakukan tentang pengaruh pertumbuhan ekonomi dan investasi terhadap ketimpangan pendapatan di kabupaten/kota Provinsi Nusa Tenggara Barat tahun 2012-2016, diperoleh kesimpulan bahwa Pertumbuhan ekonomi ditunjukkan dalam persentase yang didapat dari peningkatan Produk Domestik Regional Bruto Atas Dasar Harga Konstan (PDRB ADHK) Provinsi Nusa Tenggara Barat dari tahun ke tahun. Variabel ini menunjukan pengaruh yang positif dan signifikan terhadap ketimpangan pendapatan antar daerah. Pengaruh yang dihasilkan sebesar 0,1511 , hal ini menunjukkan bahwa pertumbuhan ekonomi yang terjadi tidak sama pada beberapa daerah dapat menyebabkan meningkatnya ketimpangan pendapatan. Investasi didapatkan dari Penanaman Modal Asing (PMA) di kabupaten/kota Provinsi Nusa Tenggara Barat dalam kurun waktu lima tahun. Vriabel ini menunjukan pengaruh positif dan tidak signifikan terhadap ketimpangan pendapatan. Pengaruh Penanaman Modal Asing terhadap ketimpangan pendapatan (Indeks Williamson) sebesar 0,003, dengan taraf signifikansi lebih dari $5 \%$. Hal ini menunjukan bahwa pengaruh yang timbul 
diakibatkan oleh meningkatnya penanaman modal asing terhadap ketimpangan pendapatan tidak besar atau signifikan.

Berdasarkan pada hasil yang diperoleh dan kesimpulan, saran yang dapat disampaikan kepada pemerintah Provinsi Nusa Tenggara Bara untuk mempertimbangkan melakukan pemerataan pada perumbuhan ekonomi demi mengurangi ketimpangan yang terjadi antar kabupaten/kota. Selain itu diperlukan usaha untuk meningkatkan minat investor untuk melakukan investasi pada daerah-daerah dengan nilai investasi yang rendah, agar terjadi pemerataan. Pertumbuhan ekonomi dan investasi secara simultan berpengaruh terhadap ketimpangan pendapatan. Dalam upaya mengurangi ketimpangan pendapatan serta demi mencapai kesejahteraan masyarakat, pemerintah daerah dapat melakukan evaluasi terhadap potensi daerah sehingga dapat mencapai pemerataan.

\section{DAFTAR PUSTAKA}

Adipuryanti, N. L. Y., \& Sudibia, I. K. (2013). Analisis Pengaruh Jumlah Penduduk Yang Bekerja Dan Investasi Terhadap Ketimpangan Distribusi Pendapatan Melalui Pertumbuhan Ekonomi Kabupaten/Kota Di Provinsi Bali. Jurnal Kependudukan Dan Pengembangan Sumber Daya Manusia, XI(1), 20-28. https://doi.org/10.1016/j.actaastro.2014.11.036

Aggina, D., \& Artaningtyas, W. D. (2017). Pengaruh Pertumbuhan Ekonomi, Pertumbuhan Penduduk, Pertumbuhan Investasi, dan Indeks Pembangunan Manusia Terhadap Ketimpangan Distribusi Pendapatan di Daerah Istimewa Yogyakarta Tahun 2007-2014. Buleti Ekonomi, 15, 1-154.

Arifin, Z. (2012). Analisis Perbandingan Perekonomian Pada Empat Koridor di Propinsi Jawa Timur. Jurnal Humanity, 5.

Boedirachminarni, A., \& Suliswanto, M. S. W. (2017). PENGEMBANGAN EKOWISATA DI KABUPATEN MALANG. Jurnal Ekonomi Pembangunan UMM, 15, 105-116.

BPS Nusa Tenggara Barat. (n.d.). Badan Pusat Statistik Nusa Tenggara Barat. Retrieved from https://ntb.bps.go.id/

Hartini, N. T. (2017). Pengaruh PDRB Perkapita, Investasi dan IPM Terhadap Ketimpangan Pendapatan Antar Daerah Di Provinsi DIY Tahun 2011-2015. Jurnal Pendididkan Dan Ekonomi, 6(6), 530-539. Retrieved from nitatrihartini@gmail.com

Kuncoro, M. (2004). Analisis Spasial san Regiona, Studi Aglomerasi dan Kluster Industri Indonesia (kedua). Yogyakarta: UPP AMP YKPN.

Kusuma, H. (2016). Desentralisasi Fiskal dan Pertumbuhan Ekonomi di Indonesia. Jurnal Ekonomi Kuantitatif Terapan, 9.

Nangarumba, M. (2015). Analisis Pengaruh Struktur Ekonomi, Upah Minimum Provinsi , Belanja Modal, dan Investasi Terhadap Ketimpangan Pendapatan di Seluruh Provinsi di Indonesia Tahun 2005-2014. Jesp, 7(2), 926.

Nuraini, I. (2012). Analisis Sumber-Sumber Pertumbuhan Output Regional Kota Malang, 5, 109-115. 
Pradnyadewi, D., \& Purbadharmaja, I. B. (2017). Pengaruh IPM, Biaya Infrastruktur, Investasi Dan Pertumbuhan Ekonomi Terhadap Ketimpangan Distribusi Pendapatan Di Provinsi Bali. E-Jurnal EP Unud, 6(2), 255-285.

Saputra, N. C. (2016). Analisis pengaruh pertumbuhan ekonomi, pengangguran,dan indeks pembangunan manusia terhadap ketimpangan pendapatan antar kabupaten/kota di Provinsi jawa timur. Malang.

Sukirno, S. (2006). Ekonomi Pembanguanan, Proses, Masalah dan Dasar Kebijakan. Jakarta: Kencana.

Sultan, \& Sodik, J. (2010). Analisis Ketimpangan Pendapatan Regional Di DIY-Jawa Tengah Serta Faktor-Faktor Yang Mempengaruhi Periode (20002004). Buletin Ekonomi, 8(1), 1-70.

Susilowati, D., Sri, M., \& Suliswanto, W. (2015). MANUSIA, UTANG LUAR NEGERI DAN KEMISKINAN ( KAJIAN TEORITIS DI INDONESIA ), 89-106.

Todaro, M. P., \& Smith, S. C. (2011). Pembangunan Ekonomi (kesebelas). Jakarta: Erlangga.

Yuliani, T. (2014). Pertumbuhan Ekonomi dan Ketimpangan Pendapatan Antar kabupaten di kalimantan Timur. JEJAK, 8(Journal of Economics and Policy).

https://doi.org/http://dx.doi.org/10.15294/jejak.v7i1. 